

\title{
Reply to the comment on the paper "Lago Mare and the Messinian Salinity Crisis: Evidence from the Alboran Sea (S. Spain) by Do Couto et al. (2014) Marine and Petroleum Geology 52 (57e76)" authored by Serrano and Guerra-Merchan
}

Damien Do Couto Do Couto, Speranta-Maria Popescu, Jean-Pierre Suc, Mihaela Carmen Melinte-Dobrinescu, Nadia Barhoun, Christian Gorini, Laurent Jolivet, Jeffrey Poort, Gwenaël Jouannic, Jean-Luc Auxietre

\section{To cite this version:}

Damien Do Couto Do Couto, Speranta-Maria Popescu, Jean-Pierre Suc, Mihaela Carmen MelinteDobrinescu, Nadia Barhoun, et al.. Reply to the comment on the paper "Lago Mare and the Messinian Salinity Crisis: Evidence from the Alboran Sea (S. Spain) by Do Couto et al. (2014) Marine and Petroleum Geology 52 (57e76)" authored by Serrano and Guerra-Merchan. Marine and Petroleum Geology, 2015, 65, pp.340-342. 10.1016/j.marpetgeo.2014.10.007 . hal-01250176

\author{
HAL Id: hal-01250176 \\ https://hal.science/hal-01250176
}

Submitted on 4 Jan 2016

HAL is a multi-disciplinary open access archive for the deposit and dissemination of scientific research documents, whether they are published or not. The documents may come from teaching and research institutions in France or abroad, or from public or private research centers.
L'archive ouverte pluridisciplinaire HAL, est destinée au dépôt et à la diffusion de documents scientifiques de niveau recherche, publiés ou non, émanant des établissements d'enseignement et de recherche français ou étrangers, des laboratoires publics ou privés. 


\title{
Reply to the comment on the paper "Lago Mare and the Messinian Salinity Crisis: Evidence from the Alboran Sea (S. Spain) by Do Couto et al. (2014) Marine and Petroleum Geology 52 (57-76)" authored by Serrano and Guerra-Merchán
}

\author{
Damien Do Couto ${ }^{1}$, Speranta-Maria Popescu ${ }^{2}$, Jean-Pierre Suc ${ }^{3-4}$, \\ Mihaela Carmen Melinte-Dobrinescu ${ }^{5}$, Nadia Barhoun ${ }^{6}$, Christian Gorini ${ }^{3-4}$, Laurent Jolivet ${ }^{7}$, \\ Jeffrey Poort $^{3-4}$, Gwénaël Jouannic ${ }^{8}$, Jean-Luc Auxietre ${ }^{9}$
}

1, Section of Earth and Environmental Sciences, University of Geneva, 13 rue des Maraîchers, CH-1205, Geneva, Switzerland (damien.docouto@unige.ch)

2, GeoBioStratData.Consulting, 385 route du Mas Rillier, 69140 Rillieux la Pape, France (speranta.popescu@gmail.com)

3, Sorbonne Universités, UPMC Univ. Paris 06, UMR 7193, Institut des Sciences de la Terre Paris (iSTeP), 75005 Paris, France

4, CNRS, UMR 7193, Institut des Sciences de la Terre Paris (iSTeP), 75005 Paris, France (jeanpierre.suc@gmail.com, christian.gorini@gmail.com, jeffrey.poort@upmc.fr)

5, National Institute of Marine Geology and Geoecology, 23-25 Dimitrie Onciul street, P.O. Box 34-51, 70318 Bucharest, Romania (melinte@geoecomar.ro)

6, University Hassan II-Mohammedia, Faculty of Sciences Ben M'Sik, BP 7955 Sidi Othmane, Casablanca, Morocco (nbarhoun@yahoo.fr)

7, Université d'Orléans, ISTO, UMR 7327, 45071 Orléans, France

CNRS/INSU, ISTO, UMR 7327, 45071 Orléans, France

BRGM, ISTO, UMR 7327, BP 36009, 45060 Orléans, France

(laurent.jolivet@univ-orleans.fr)

8, Cerema, DTer Est, Laboratoire Régional des Ponts et Chaussées de Nancy, 54510 Tomblaine, France (gwenael.jouannic@cerema.fr)

9, TOTAL, 2 place Jean Millier, 92400 La Défense, Paris, France (jean-luc.auxietre@total.com)

\section{Corresponding author}

Damien Do Couto, Section of Earth and Environmental Sciences, University of Geneva, 13 rue des Maraîchers, CH-1205, Geneva, Switzerland (damien.docouto@unige.ch)

\begin{abstract}
The marine context of the Lago Mare deposit near Malaga has received agreement as well as its ascription to the third Lago Mare event of Clauzon et al. (2005). This deposit is not a "transitional unit towards normal marine conditions" but followed the marine reflooding of the Mediterranean Basin, allowing the connection with the Dacic Basin (Eastern Paratethys). We show that this Lago Mare event did not result from a climatic change leading to a dilution episode but from a high sea-level connection. Different interpretations on the respective effects of tectonics and eustatism on the sedimentary archives linked to the Messinian Salinity Crisis (MSC) are once more debated. They depend on (1) the duration assigned to the MSC and its subdivisions, (2) the amplitude of the successive sea level variations, and at last (3) the dimensional (local or regional) view of the MSC. Such discrepancies concern subsidiary matters which cannot mask first order facts and progresses in their knowledge.
\end{abstract}

Key-words: Alboran Sea, Post-Messinian Crisis reflooding, Lago Mare, Mediterranean Paratethys high sea-level connection 
We welcome the opportunity to answer this comment that mixes up first order and secondary aspects of the Messinian Salinity Crisis which are worth distinguishing. Accordingly, our reply first concerns the new context of the Malaga Lago Mare which is partly accepted by Serrano and Guerra-Merchán. Then, we return to the old debate on the respective impact of tectonic activity and sea-level changes during and just after the Messinian Salinity Crisis (MSC) which, at last, affect the interpretation of the Messinian - Zanclean archives.

\section{Marine context of the Malaga Lago Mare deposition}

As a major conclusion of the paper by Do Couto et al. (2014), we showed that the Lago Mare (LM) of the Malaga area has been deposited during a marine context of high sea level that is agreed by Serrano and Guerra-Merchán. It corresponds to the LM 3 event (Clauzon et al., 2005) that is not questioned by these authors. We interpret this event as the consequence of the fast marine reflooding of the Mediterranean Basin which resulted from the collapse of the Gibraltar sill (Garcia-Castellanos et al., 2009) and rapidly allowed the connection with the Paratethyan Dacic Basin (Bache et al., 2012). This is the only way to explain the large amounts of mixed Atlantic and Paratethyan fossils (calcareous nannofossils, foraminifers, molluscs, and dinoflagellate cysts on the one hand, ostracods, molluscs and dinoflagellate cysts on the other hand; Guerra-Merchán et al., 2010; Do Couto et al., 2014). Serrano and Guerra-Merchán interpret the marine character of the LM 3 episode as resulting from initiated brief and repeated oceanic overflows into a brackish Mediterranean Basin. On contrary, our palaeobiological data show that this LM 3 episode results from only one event, the massive entrance of oceanic waters into an almost desiccated Mediterranean Basin.

The Serrano and Guerra-Merchán's hypothesis also invokes peculiar climatic conditions at the time of LM 3 "with a positive hydrological budget (rainfall + runoff > evaporation), contrary to the present-day one", plus restricted water exchanges through the Gibraltar Strait that together might have led to water stratification (Guerra-Merchán et al., 2014). However, an abundant pollen documentation shows that the southwestern Mediterranean climate was significantly warmer and drier than today prior to the MSC, during its first step (as defined by Clauzon et al., 1996) and immediately after the MSC that includes the LM 3 event (Fauquette et al., 2006; Jiménez-Moreno et al., 2010; Feddi et al., 2011). The regional documentation is now completed in deep sea cores (DSDP - ODP Sites 134, 976, and 978) by the record of the three successive LM events (Clauzon et al., 2005) which occurred in the same warm and dry climatic conditions (Popescu et al., submitted). The pollen content of our sample 6 from the Río Mendelín Lago Mare (Do Couto et al., 2014: figure 3), characterized by 56\% of herbs including subdesertic plants, locally confirms these climatic conditions. Increased runoff and subsequent water stratification (i.e., anoxic conditions on the sea floor) must result in abundant amorphous organic matter in the palynological slides (Suc et al., 2010), a phenomenon that we did not observe in the Alboran Sea. These data contradict the Serrano and Guerra-Merchán's climatic hypothesis. Thus, the assumption of the Lago Mare being a dilution event as concluded by Rouchy and Caruso, 2006 is not supported.

\section{Tectonic versus eustatism}

Serrano and Guerra-Merchán argue that tectonics may have played a major role in the stratigraphic succession observed at the Río Mendelín section. We agree that tectonics was active between the deposition of the Lago Mare and the subsequent yellowish clays (Do Couto et al., 2013: figure 3) as attested by the occurrence of syn-sedimentary normal faults. However the authors assumed that "tectonics could have played a more radical role at the end of the Messinian" (Guerra-Merchán et al., 2010). This is an old debate to which we are often 
confronted regarding the post-MSC sedimentation. Actually, the debate concerns the respective influence of the sea-level change, with outstanding amplitude in our opinion, and the tectonic activity. Regarding this, two main points must be considered:

- a local view of the MSC, particularly in a very active tectonic area such as the Gibraltar arc, leads to consider the effects of tectonics prevailing over those of eustatism. However, at the Mediterranean scale, the widespread occurrence of post-MSC Gilbert-type fan deltas observed on all types of margins, whether active or passive (Bache et al., 2012) forces to incline towards a generalized response to this unique event, without neglecting the local synor post-sedimentary tectonics;

- the sea-level fall and rise opening and closing the MSC are estimated between 1000 and $1500 \mathrm{~m}$ (Bache et al., 2012; Gargani et al., 2014) which, in a very short time (140 kyrs; Bache et al., 2012), is more than one order of magnitude larger than the maximum tectonic uplift estimated in the studied area for a significantly longer time (e.g. $100 \mathrm{~m}$; Guerra-Merchán et al., 2014).

\section{Post-MSC Gilbert-type fan deltas}

Without repeating the arguments in favour of two coalescing Gilbert-type fan deltas at El Túnel and Río Mendelín already detailed in Do Couto et al. (2014), we now focus on four items questioned by Serrano and Guerra-Merchán:

- according to the ages indicated by the calcareous nannoflora, there is no reason to envisage a polyphased erosional surface in which the Gilbert-type fan deltas are nested. This is actually the Messinian Erosional Surface as now accepted by Serrano and Guerra-Merchán;

- the record of the calcareous nannofossil species Triquetrorhabdulus rugosus without Ceratolithus acutus at El Túnel suggests that these deltaic sediments are older than those at Río Mendelín where these species have been recorded together (Raffi et al., 2006), i.e. sample 5 (Do Couto et al., 2014: table 1);

- the thin iron-rich horizons in the Río Mendelín section, considered as "hard-ground surfaces" in relation with tectonic movements, are very common concentrated horizons in the bottomset beds of the post-MSC Gilbert-type fan deltas, more unsurprising with respect to the sierras as a source in the hinterland;

- whereas Serrano and Guerra-Merchán attribute the conglomerates topping the Río Mendelín section to "post-Zanclean probably Upper Pleistocene (Tyrrhenian)" age, there is in fact no datation contradicting our ascription to the topset beds of the Gilbert-type fan delta.

\section{Conclusion}

We mainly reiterate the conclusions of the Do Couto et al. (2014)'s paper, particularly concerning the full marine context of the Lago Mare deposit at Río Mendelín which immediately overlies the Messinian Erosional Surface and belongs to a Gilbert-type fan delta. This Lago Mare episode is the LM 3 defined by Clauzon et al. (2005) which immediately followed the brutal marine reflooding of the Mediterranean Basin, that momentarily allowed connection between the Mediterranean Sea and Dacic Bassin ( Popescu et al., 2009; Bache et al., 2012).

We appreciate the agreement of Serrano and Guerra-Merchán on some of these major points and we thank them to have offered us the opportunity to reassert our interpretations such as the LM 3 is not a "transitional unit towards normal marine conditions" but was deposited in a full marine context. Some minor items depend on interpretation, such as (1) the two Lago 
Mare sequences for Serrano and Guerra-Merchán that we consider the prograding passage from foreset to bottomset beds, or (2) the origin of the erosional contact between the Lago Mare deposits and the Zanclean ones referred by Serrano and Guerra-Merchán to a sea-level fall and to submarine gravity instability by us.

\section{Acknowledgements}

Field trips and micropaleontological analyses have been supported by the CIFRE PhD grant No 584/2010 (TOTAL/UPMC) and by the CNRS/INSU “Actions Marges” Program.

\section{References}

Bache, F. Popescu, S.-M., Rabineau, M., Gorini, C., Suc, J.-P., Clauzon, G., Olivet, J.-L., Rubino, J.-L., Melinte-Dobrinescu, M.C., Estrada, F., Londeix, L., Armijo, R., Meyer, B., Jolivet, L., Jouannic, G., Leroux, E., Aslanian, D., Dos Reis, A.T., Mocochain, L., Dumurdžanov, N., Zagorchev, I., Lesić, V., Tomić, D., Çağatay, M.N., Brun, J.-P., Sokoutis, D., Csato, I., Ucarkus, G., Çakir, Z., 2012. A two-step process for the reflooding of the Mediterranean after the Messinian Salinity Crisis. Basin Research 24, 125-153.

Clauzon, G., Suc, J.-P., Gautier, F., Berger, A., Loutre, M.-F., 1996. Alternate interpretation of the Messinian salinity crisis: Controversy resolved? Geology 24(4), 363-366.

Clauzon, G., Suc, J.-P., Popescu, S.-M., Mărunţeanu, M., Rubino, J.-L., Marinescu, F., Melinte, M.C., 2005. Influence of the Mediterranean sea-level changes over the Dacic Basin (Eastern Paratethys) in the Late Neogene. The Mediterranean Lago Mare facies deciphered. Basin Research 17, 437-462.

Do Couto, D., Popescu, S.-M., Suc, J.-P., Melinte-Dobrinescu, M.C., Barhoun, N., Gorini, C., Jolivet, L., Poort, J., Jouannic, G., Auxietre, J.-L., 2014. Lago Mare and the Messinian Salinity Crisis: Evidences from the Alboran Sea (S. Spain). Marine and Petroleum Geology 52, 57-76.

Fauquette, S., Suc, J.-P., Bertini, A., Popescu, S.-M., Warny, S., Bachiri Taoufiq, N., Perez Villa, M.-J., Chikhi, H., Subally, D., Feddi, N., Clauzon, G., Ferrier, J., 2006. How much did climate force the Messinian salinity crisis? Quantified climatic conditions from pollen records in the Mediterranean region. Palaeogeography, Palaeoclimatology, Palaeoecology 238(1-4) 281-301.

Feddi, N., Fauquette, S., Suc, J.-P., 2011. Histoire plio-pléistocène des écosystèmes végétaux de Méditerranée sud-occidentale: apport de l'analyse pollinique de deux sondages en mer d'Alboran. Geobios 44, 57-69.

Garcia-Castellanos, D., Estrada, F., Jiménez-Munt, I., Gorini, C., Fernàndez, M., Vergés, J., De Vicente, R., 2009. Catastrophic flood of the Mediterranean after the Messinian salinity crisis. Nature 462, 778-782.

Gargani, J., Bache, F., Jouannic, G., Gorini, C., 2014. Slope destabilization during the Messinian Salinity Crisis. Geomorphology 213, 128-138.

Guerra-Merchán, A., Serrano, F., Garcés, M., Gofas, S., Esu, D., Gliozzi, E., Grossi, F., 2010. Messinian Lago-Mare deposits near the Strait of Gibraltar (Malaga Basin, S Spain). Palaeogeography, Palaeoclimatology, Palaeoecology 285, 264-276.

Guerra-Merchán, A., Serrano, F., Hlila, R., El Kadiri, K., Sanz de Galdeano, C., Garcés, M., 2014. Tectono-sedimentary evolution of the peripheral basins of the Alboran Sea in the arc of Gibraltar during the latest Messinian-Pliocene. Journal of Geodynamics 77, $158-170$. 
Jiménez-Moreno, G., Fauquette, S., Suc, J.-P., 2010. Miocene to Pliocene vegetation reconstruction and climate estimates in the Iberian Peninsula from pollen data. Review of Palaeobotany and Palynology 162, 403-415.

Popescu, S.-M., Dalesme, F., Jouannic, G., Escarguel, G., Head, M.J., Melinte-Dobrinescu, M.C., Sütő-Szentai, M., Bakrac, K., Clauzon, G., Suc, J.-P., 2009. Galeacysta etrusca complex, dinoflagellate cyst marker of Paratethyan influxes into the Mediterranean Sea before and after the peak of the Messinian Salinity Crisis. Palynology 33(2), 105-134.

Popescu, S.-M., Dalibard, M., Suc, J.-P., Barhoun, N., Melinte-Dobrinescu, M.C., Bassetti, M.A., Deaconu, F., Head, M.J., Gorini, C., Do Couto, D., Rubino, J.-L., Auxietre, J.-L., Floodpage, J., submitted. Messinian - Zanclean boundary and Lago Mare events in the deep southwestern Mediterranean. Marine and Petroleum Geology.

Raffi, I., Backman, J., Fornaciari, E., Pälike, H., Rio, D., Lourens, L., Hilgen, F., 2006. A review of calcareous nannofossil astrobiochronology encompassing the past 25 million years. Quaternary Science Reviews 25, 3113-3137.

Rouchy, J.M., Caruso, A., 2006. The Messinian salinity crisis in the Mediterranean basin: a reassessment of the data and integrated scenario. Sedimentary Geology 188-189, 35-67.

Suc, J.-P., Combourieu-Nebout, N., Seret, G., Popescu, S.-M., Klotz, S., Gautier, F., Clauzon, G., Westgate, J., Sandhu, A.S., 2010. The Crotone series: a synthesis and new data. Quaternary International 219, 121-133. 